\title{
Everything you always wanted to know about ... The Sex Education Show
}

\section{Susan Quilliam}

\section{Background}

British-based Journal readers may recall, in the autumn of 2008, a sudden explosion of shock-horror headlines in the press about a new television series. Channel 4's The Sex Education Show was apparently being just too upfront and personal about all kinds of sexual issues and, even more appallingly, was aimed at teens as well as adults and was scheduled before the watershed of $9.00 \mathrm{pm}$. Personally, and professionally, I thought it a brave and useful project. But I was fascinated to peep behind the scenes and see what the programme-makers really intended, and whether my family-planning-informed enthusiasm was well justified.

I approached the relevant production company, Endemol, with some trepidation. Given the aforementioned press negativity, I was prepared for not only refusal to be interviewed but also defensiveness if the interview did take place. In the event, neither fear was realised. What I got was absolute co-operation - even to the point of offering to let me see the complaints the series received. The press office was accommodating, the production team willing, and a few weeks later I found myself posing my questions to producer, Adeline Ramage Rooney.

\section{Agenda}

To begin with, I asked what had the programme-makers' agenda been? Adeline's answer: "to get people talking". But by this the intention was not to cause controversy and hit the tabloid headlines; instead their mission was get their adolescent viewers talking to each other ('the school playground water cooler moment') and then get them talking to the adult viewers. "We hoped that a teen would watch it in the bedroom while their Mum watched it in the front room - and that maybe some time over the next 24 hours the two would discuss [sex] without embarrassment."

Encouragingly, that entire agenda came from the teenagers themselves, who told the programme-makers: "We are still children and we need to learn, but our parents think we know it all and won't talk about it to us". In our sexualised society, what the press and public perhaps don't realise is that there is not only a need to give young people knowledge, values and guidance, but also a need to help parents understand that whatever their seeming recalcitrance, teens need those things and want trusted adults to deliver. "Television ... makes knowledge more credible per se - it also makes guidance more acceptable, less state-dictated."

The project agenda was firmed up - and has been continuously updated over the course of the first, second and now upcoming third series - not only with focus groups but also via a YouGov Survey of 1300 teenagers, and via roadshow work in schools that invited the programme-makers in. Also involved were experts from a

J Fam Plann Reprod Health Care 2010; 36(1): 39-40

\section{Cambridge, UK}

Susan Quilliam, BA, Cert Ed, MNLP, Freelance Writer, Broadcaster and Agony Aunt

Correspondence to: Ms Susan Quilliam.

E-mail: susan@susanquilliam.com wide range of British sexual health and education organisations such as Brook, the Sex Education Forum, the fpa (Family Planning Association) and the Terence Higgins Trust.

\section{Format and cast}

How to deliver on screen? The key words here, reports Adeline, were "educational ... entertaining ... engaging ... different ... fun ... light-hearted ... moral ... unpatronising ... non-exploitative ... supportive of teenagers". So Yes to clear facts, clear warnings, a realistic representation of what teenagers are concerned about - and a sense of what's right and what's wrong. But No to scaremongering. No to position of the week. No to anything that suggested all teenagers are "at it". And double No to anything that could approach sleaze. Then, add on an accompanying website to continue the support after the show was aired.

As to programme format and 'shape', it soon became clear that there were no precedents. The team didn't even spend much time looking at previous sex education videos ("it's a completely different market") or sexual pleasure DVDs ("our job is not to show people how to have sex"). In addition, it proved impossible to set a standardised format, à la Wife Swap or Come Dine with Me, because that would have alienated the impossibly diverse audience. "We needed a magazine format, which appealed to everyone, covered all the bases, but still maintained the same core messages."

\section{No to scaremongering. \\ No to position of the week. No to sleaze.}

The 'cast' of the show were ordinary schoolchildren from a variety of backgrounds, carefully briefed and with full parental consent, plus a raft of specialist experts. The presenter, with a pivotal role, needed to be someone at ease with sensitive and sometimes embarrassing material, someone who could ask challenging questions, but also someone who could wear their heart on their sleeve and be prepared, for example, to have an STI test live on camera!

The programme-makers decided on Anna Richardson, an established TV personality - a decision not always welcomed by critics, who felt that a sexual health specialist would have been a more appropriate choice. Adeline says: "We didn't go that route in case it gave a preachy feel or in case an expert felt they had to be so formal in their dealings that it took the heart out of the series. In the end we made the right choice. Anna has not only been great on camera, off-camera she's also been great; for example, in one programme she ended up comforting a girl who'd had an abortion."

\section{Critical reception}

Decisions confirmed, experts consulted, scripts written, team hired, filming went ahead and the first series was aired in September 2008. As mentioned, reception was mixed. The Daily Mail ran a half page of scathing accusations including the words "Channel 4 has been accused of peddling obscenity". One sexual health 
organisation - tactfully the Endemol spokesperson refused to say which one - was very critical and withdrew support. Reportedly 152 viewers rang in to complain, particularly about the use of real-life models. There were many who argued that The Sex Education Show quite simply went too far. Ofcom was called in to investigate.

The programme-makers were unfazed. Yes, they had expected, albeit not courted, press wobbles. Yes, they were saddened by individual and organisational objections "some people seemed to think we didn't care about the teenagers, but we do, very much". Yes, they acknowledged, and later rectified, an initial heterosexual bias and certain difficulties with spanning such a wide viewer market aged $13+$ years to adult. But they were confident that they had acted thoughtfully and responsibly, with an army of advisors and lawyers checking "every image, every script, every voiceover".

As to the tabloid-outraging real models issue, this approach was "actually suggested by the sexual health organisations, which wanted us to dispel harmful myths about body image and sexual performance that are rife on the Internet".

And when Ofcom did investigate, looking at every single complaint, it totally cleared the series, stating that it not only fulfilled its brief to "examine sex and sexual health in an accessible way that would engage viewers" but that it also responsibly gave clear warning of explicit content pre-transmission, at the start of each programme and throughout it. The regulator, in fact, strongly backed the whole project, saying that it was "of paramount importance" that such issues were covered in the media and that it would be a "an inappropriate and a disproportionate limitation on the freedom of speech" to prohibit programmes of this nature, even before the watershed.

\section{Positive reception}

Adeline and her colleagues had further reasons to be cheerful. A resounding $99 \%$ of the feedback was positive. "[The very day after the first programme was aired] we started to get [messages] coming in from people saying how much they loved it." Parents wrote in to express their gratitude, saying things like "Thank you so much, I've now got a genuine reason to start a conversation about contraception rather than trying to shoehorn it into everyday life". Sex and relationship educators constantly asked for the series DVD. Much press coverage was supportive and grateful. "The UK could do with a bit of sex education", commented The Independent. And - scoop of the year - Cameron Diaz (some Journal readers may need me to point out that she's a film star) when interviewed for Cosmopolitan magazine, stated that she watched the programme, loved it, and thought it was just what America needed. Dear reader, what further endorsement does one need?

\section{I've now got a genuine reason to start a conversation about contraception.}

Most importantly of all, surely, was the positive response from teenagers. E-mail after e-mail congratulated the show. In schools visited by the programme-makers, class after class learned and loved learning. The show's website (http://www.sexperienceuk.channel4.com) - by the time I spoke to Adeline - generated over 22 million hits and that figure has no doubt risen since. Indeed, at one point if you Googled ${ }^{\mathrm{TM}}$ the word 'sex', the show was the number one site found. "What we always wanted was to create an arena where Jessie from Milton Keynes could say 'I occasionally get this fishy smell downstairs after having sex, though I'm really clean', and get [good] advice. It's all about people sharing their experience."

\section{Next steps}

How has the concept changed since its controversial launch? The first series covered a multitude of topics, from period pains to penis size, STIs to fertility testing. But by the time the project was recommissioned for 2009, the focus had become tighter; the second series homed in on the pornification of society and how it affects teens. Slid over and past the watershed to allow more graphic content and screened on consecutive nights over the course of a week, that series made hardly a stir in the press, attracted few complaints (which Ofcom deemed it irrelevant to even investigate) and not only created 'school water cooler' and teen-parent conversations à la the programme-makers' original brief, but also gathered a dedicated fan base across a wider age range.

\section{We want to say that sex is good and fun, but you need to look after yourself.}

What of the future? Surely a continuing website. Surely more schools using the DVDs. Hopefully - there is already evidence of this in other TV channels' commissioning strategies - a society-wide impact on the whole field of responsible but accessible sex education.

And, certainly, a third series. Though sworn to secrecy on the details, your intrepid correspondent can reveal that a third series will air in Summer 2010 and address diversity of sexuality. "We want to give a voice to the sexually invisible - the disabled, the older. We want to cover stories of people who have overcome incredible prejudice to claim their right to a sex life, but once again we want to put that across not in a sensationalised way but with an underlying message that sex is good and fun, but you need to look after yourself."

\section{And finally}

I was left, following my research and my interviews, with any doubts assuaged, feeling positive not only about the focus of The Sex Education Show, but also about the intentions and capabilities of its makers. And I leave you with the very encouraging thought that when I asked Adeline whether the project had affected those who worked on it, the answer was a resounding Yes. "Absolutely. Every single member of the team has learned a lot and had their eyes opened. We've now made a pact with ourselves that if we have younger friends, cousins, nieces or daughters who are approaching puberty and [having wobbles about sexuality], we won't fall into the trap of thinking that it's not our place to say anything. Instead, we'll sit down with them, talk it through, and make sure they're happy." Whatever the tabloids shriek, as a personal and professional philosophy, surely you can't say fairer than that?

Statements on funding and competing interests

Funding None identified.

Competing interests None identified.

Author's note

A third series of The Sex Education Show will air on Channel 4 in Summer 2010. 